\title{
Ethnologies
}

\section{The Annotated Classic Fairy Tales. By Maria Tatar, editor and translator. (New York \& London: W. W. Norton \& Company, 2002. Pp. 448, ISBN: 0-393-051-633, hardcover.)}

\section{Diane Tye et Callum Latta}

Volume 25, numéro 2, 2003

Language and Culture / Langue et culture

URI : https://id.erudit.org/iderudit/008059ar

DOI : https://doi.org/10.7202/008059ar

Aller au sommaire du numéro

Éditeur(s)

Association Canadienne d'Ethnologie et de Folklore

ISSN

1481-5974 (imprimé)

1708-0401 (numérique)

Découvrir la revue

Citer ce compte rendu

Tye, D. \& Latta, C. (2003). Compte rendu de [The Annotated Classic Fairy

Tales. By Maria Tatar, editor and translator. (New York \& London: W. W.

Norton \& Company, 2002. Pp. 448, ISBN: 0-393-051-633, hardcover.)]

Ethnologies, 25(2), 246-249. https://doi.org/10.7202/008059ar d'utilisation que vous pouvez consulter en ligne.

https://apropos.erudit.org/fr/usagers/politique-dutilisation/ 
at the end of the book. She also offers a map but with only a small subset of the place names. I would have liked a more detailed map.

There is a certain amount of redundancy in the book. The Alta River crisis is discussed in several chapters for instance. But perhaps this is the very means by which certain historical turning points are consciously imbued with symbolic currency. While Lehtola is clear about his opinions, he is careful to acknowledge divergent views. Occasionally, he offers a questionable generalization. The one that disturbed me, as much for its lack of clarity as its excess, was the statement that the yoik was the "most aboriginal of musics." What could that mean?

Overall, however, this book was a succinct exploration of well known events but the presentation of these events was remarkably nuanced by the acknowledgment of diversity within the community and by the clear presentation of contentious issues. Furthermore, the important role of expressive culture as a means of mediating tradition and modernity, indeed a means of denying that these are polarized, is given not only a nod but a lively examination. The bridge building that Lehtola achieves here would, I think, be heartily applauded by the remarkable compatriot, Nils Aslak Valkeappa, whose memory it celebrates.

Beverley Diamond Memorial University of Newfoundland

The Annotated Classic Fairy Tales. By Maria Tatar, editor and translator. (New York \& London: W. W. Norton \& Company, 2002. Pp. 448, ISBN: 0-393-051-633, hardcover.)

My eight-year-old son, Callum, and I enjoy reading together. We have eclectic taste and over the years have read most of the children's classics and lots of popular culture titles. Callum's recent preference for nonfiction has taken us in many new directions, from biology to volcanoes to trivia. However, one genre we have not explored together is fairy tales so when I saw the announcement of Maria Tatar's new collection The Annotated Classic Fairy Tales I jumped at the opportunity to return to a group of well-known fairy tales and to share them with Callum. I have a clear memory of my own father reading me Grimm's fairy tales when I was about his age and I've drawn on those stories 
personally and professionally many times for, as Tatar describes the tales in her volume, these are "the stories that we all think we know - even when we are unable to tell them..." (xiv). It was a cultural legacy I wanted to share with my son. However, a collection of fairy tales would not have been Callum's choice for our first collaborative book review. In fact, his initial response was: "I hate reading fairy tales. They're boring."

We made our way through the more than two dozen selected stories in Tatar's collection from Grimms' "Little Red Riding Hood," and "Hansel and Gretel" to Perrault's "Cinderella," and "Bluebeard," and Hans Christian Anderson's "The Emperor's New Clothes" and the "Little Match Girl." Maria Tatar succeeds in her goal of creating versions that are easily read or told; these are stories for sharing orally. And, the oral nature of the volume doesn't end with the stories' texts. She contextualizes the narratives extremely well, offering information on oral storytelling traditions, biographies of collectors and countless annotations that lead adult readers to key themes and interpretations. By the end of the book, Callum and I had talked both about these stories as part of an adult storytelling tradition and about the men who first collected or composed them. Although Callum didn't read these parts - Tatar notes that she intends these as supplements for the adult reader - Callum conceded, "I learned a bit of history." I actually figured he got as much background here as students take away from the folktale section of a Folklore 1000 survey course. Most of all, we discussed ways in which many of the stories had been recreated as children's literature or Disney movies. In fact, identifying changes and thinking about the ways in which they altered meanings was the aspect that Callum most enjoyed: "The older stories were a bit better than the fairy tales I had heard before because there was more killing so they weren't as boring... It was interesting to compare these stories with the Walt Disney movies and books because sometimes there were lots of differences but sometimes they were the same." Callum concluded that "The stories must have got a bit nicer after the parents found out that they gave the kids nightmares." Before the end of the book he was priding himself on his knowledge of earlier versions of some of the tales and had taken The Annotated Classic Fairy Tales to school to share with his class.

These stories are the most violent Callum has thus far encountered and I enjoyed watching him engage with fairy tales' lure as they captivated and repulsed him, sometimes simultaneously. The fine line Callum 
walked between fascination and horror can be seen in his response when I asked which story he liked the best: "Little Red Riding Hood because they cut the stomach open of the wolf. It was a bit grosser than the ones I heard before... I didn't really like Bluebeard, I guess. It was a bit too gross."

As is undoubtedly clear by now, reading The Annotated Classic Fairy Tales hasn't changed Callum's mind about the merits of fairy tales as reading material or at least his willingness to admit it. However, he admits that he'd recommend the book to "people who like fairy tales (and gross things)." Of course this now opens up the possibility that the book would appeal to all of eight-year old friends. Callum particularly liked the layout of the book and was clearly pleased to add such an impressive volume to his library. As he said: "It is a fancy book. And it is the biggest book I own." And, despite the fact that many of the reproductions of early illustrations are small, he responded to what Tatar refers to as the power of the images that accompany the narratives: "I thought they were a bit too small to be enjoyed but they were still sort of cool."

It is obvious that I was more enthusiastic (ah, the challenges of collaboration!) about this collection than Callum. I really liked the selection of stories, the oral quality of the texts and the way in which background information sparked and informed our discussion. While I appreciate how one can often trace the reinterpretations of a story through the progression of illustrations, like Callum, I was a little frustrated by how difficult it was to see the small pictures. At times I wondered if it might have been wiser to include fewer but larger examples. However, what I appreciated most were the annotations. I haven't read the other titles in Norton's annotated series but The Annotated Classic Fairy Tales is a model in annotation. Notes appear beside the text on the same page but in a separate column and another type colour. The result is that annotations always enhance and never distract from the narrative. Folklorists often find themselves in a position of trying to include quantities of supplementary material and I'm sure I'll be adapting this style of annotation for my own use sometime in the future, whatever my subject might be. These are things I take away from the book professionally but the personal enjoyment was just as rich. Reading The Annotated Classic Fairy Tales with Callum reminded me again of one of the greatest joys that children bring to our adult lives: moments to glimpse our own childhoods again. As I watched 
Callum respond breathless to the first few stories, unprepared as he was for their lurid detail, I too was caught up in the fairy tale's magic. And for a few precious minutes I was eight again reading Grimm's tales for the very first time.

Diane Tye and Callum Latta Memorial University of Newfounland

Peeking Through the Keyhole. The Evolution of North American Houses. By Avi Friedman and David Krawitz. (Montreal \& Kingston: McGillQueen's University Press, 2002. ISBN 0-773-524-398, cloth.)

Montreal architect Avi Friedman is best known for the Grow Home, an inexpensive, efficient house with a large capacity for change - if it can grow with the addition of children, so can it shrink when they leave. Both a polemic against megacities, megasuburbs and megahouses and an intelligent system for low cost housing, the Grow Home might be seen as part of the simple life movement where we really ought to be able to afford accommodating spaces in which we can live happily and freely. Peeking Through the Keyhole is an exegesis, a post-Grow Home justification of why we should be thinking smaller, kinder house thoughts.

The premise is that since the Second World War spatial practices have changed enormously. Families are smaller, fragmented; everyone works, stability in the home is no longer a shirtwaisted mum in the kitchen. The kitchen in fact is more a centre of operations where the family meets in fleeting and chance encounters. While this change has been taking place, everything else has become very large: three garages rather than one, double height living rooms, a bedroom and a kingsized mattress for each individual. Life now is wide, fast and selfish.

Friedman and Krawitz discuss this in seven chapters, dense with information and ideas, starting with the deconstruction of the kitchen, once an adjunct to the house, now the heart, the hearth, the command centre. This locational centrality is undermined however by the pluggedin nature of the house where each occupant has their own phone, TV and computer. The house has become the workplace, the school, the club - or rather the computer desk has. Electronic interface also undermines the centrality of the business district in the city, already fragmented by the demands of automobile access. The spatial 